\title{
The Politics of Performance: Transnationalism and its Limits in Former Yugoslav Popular Music, 1999-2004
}

\section{CATHERINE BAKER}

UCL School of Slavonic and East European Studies, London, UK

Correspondence Address: Catherine Baker, UCL School of Slavonic and East European Studies, University College London, Gower Street, London, WC1H 0BW, United Kingdom. Email: cbakertw1@googlemail.com

\footnotetext{
ABSTRACT This paper examines transnational relations between the Yugoslav successor states from the point of view of popular music, and demonstrates how transnational musical figures (such as Djordje Balašević, Momčilo Bajagić-Bajaga, or Ceca Ražnatović) are interpreted as symbolic reference points in national ethnopolitical discourse in the process of identity construction. Another symbolic function is served by Serbian turbofolk artists, who in Croatia serve as a cultural resource to distance oneself from a musical genre associated by many urban Croats with the ruralization (and Herzegovinization) of Croatian city space. Also, value judgements associated with both Serbian and Croatian newly-composed folk music provide an insight into the transnational negotiation of conflicting identities in the exYugoslav context. Ultimately, the paper shows how the ethnonational boundaries established by nationalizing ideologies created separate cultural spaces which themselves have been transnationalized after Yugoslavia's disintegration.
} 


\section{Former Yugoslavia and Transnational Cultural Spaces}

With the disintegration of Yugoslavia, musical activities which had previously taken place within one domestic market were necessarily re-contextualized as transnational flows of information, culture, and capital. In parallel with the political changes in Croatia and Serbia following the death of the Croatian president Franjo Tudjman in 1999 and the fall of the Serbian president Slobodan Milošević in 2000, the extension of cultural contacts enabled now-transnational musical relations between the two successor states to be re-established as legitimate recording, distribution and performance activities rather than the 'underground' practices they had largely been throughout the 1990s. This paper focuses on the re-establishment period between 2000 and 2004, when decisions whether or not to perform 'across the border' were invested with political significance by musicians and the media. At stake, from a Croatian viewpoint, was whether the national cultural space should continue to be defined by the enclosed, nationalising criteria of the 1990s, and to what extent it should accommodate newly-transnational cultural products which connoted the Yugoslav era or a present-day ethnic Other.

The concept of a transnational community employed here follows Ulf Hannerz in encompassing a "fairly continuous negotiation of meanings, values, and symbolic forms $[\ldots]$ involving the cultures of the old place and the new place" (Hannerz, 1996, pp. 99-100). Analyzing migration alone, also acknowledges other ways in which transnational flows of people, capital, or cultural products may influence individual identities (Jackson, Crang, Dwyer, 2004, p. 2). This broader approach may be applied to former Yugoslavia, to take in not only those who crossed state borders during the 
1990s' wartime upheaval, but also many others who were still left with multiple, and sometimes irreconcilable, identities, since Yugoslavia's disintegration and the reinterpretation of formerly-domestic phenomena engendered many ambiguities and tensions also experienced by transnational migrants.

Moreover, post-Yugoslav cultural spaces have also witnessed the "transnational syncretism" described by Thomas Faist as the "diffusion of culture and [the] emergence of new types - mixed identities" (Faist, 2000, p. 201). Allowance must be made here for those whose displacement was a matter of "symbolic and imaginary" geography rather than the "material" kind (Jackson, Crang, Dwyer, 2004, p. 3). Alongside the familiar concept of spatial transnationalism, indeed, there may also exist a temporal form, shaped by pronounced discontinuity between the new state narratives and some individuals' personal experience. Such individuals, just like those who are more conventionally the stock-in-trade of transnational studies, were obliged to negotiate their conflicting identities and - albeit temporally rather than spatially placed in the same circumstances of existing simultaneously in more than one social field.

One typology of approaches to transnationalism includes its function as a means of “cultural reproduction" (Vertovec, 1999, p. 451) - a suitable departure-point to analyze popular music's position in the (spatial and temporal) transnationalism of former Yugoslavia. For other theorists too, "the collective enjoyment of cultural events and goods" constitutes a definite aspect of transnationalism (Portes, Guarnizo, Landolt, 1999, p. 221). Popular music is a significant form in this respect: not only do individual consumers select "meanings, pleasures and social identities" by choosing 
one musical product over another (Fiske, 1987, p. 311), but they also express their identities socially by making value judgements about music (Russell, 1997, p. 151), using particular allusions as "boundary-markers" to project definitions of one's own group and of others' (Cohen, 1985, p. 12). Musical figures who are now considered to be transnational play a particularly strong part in this symbolism. Furthermore, the representations in the texts of "a mass-mediated image culture" may be highly revealing of socio-political ideology (Kellner, 1995, p. 60); and the controversies surrounding transnational musical activity - particularly in Croatia - have indeed offered insights into the formation of the national ethnopolitical discourse, and of similar discourses of identity.

The full matrix of former Yugoslav transnational musical flows is at least six-sided, but this paper focuses on the relationship between Croatian and Serbian musical products. This paper first reviews Croatian musical activity in Serbia and Montenegro, and Serbian musical activity in Croatia, before concentrating on Croatia to examine how certain musicians with (licit or illicit) transnational audiences have become symbolic resources for constructing a number of possible Croatian identities. Finally, it discusses the position of newly-composed folk music as itself a transnational cultural form.

\section{Croatian Musical Activity in Serbia-Montenegro and Slovenia}

Croatian artists' decisions to perform in Serbia and Montenegro have also provoked polemics; indeed, even just after Franjo Tudjman's death in December 1999, too many performances 'across the border' might still have risked a mainstream pop- 
schlager (zabavna) artist's career. ${ }^{2}$ In late 1999, several zabavna singers and groups were approached by concert organisers from Serbia and Montenegro, but criticism from the Croatian media centred on Doris Dragović when she was alleged to have agreed to perform in a Montenegrin resort for New Year 2000 alongside Hari Varešanović, Haris Džinović and Maja Nikolić (Lacko, 1999). ${ }^{3}$ While offering a lucrative commercial opportunity, the Montenegrin appearance provoked the influential president of the Croatian Musicians' Union (HGU), Paolo Sfeci, to remark that Dragović should "think about whether and how much her decision will have an effect on her career and image in Croatia" (Djilas, 1999), ${ }^{4}$ and inflicted long-term damage to Dragović's following among Hajduk Split's Torcida fan-club (Gall, 2001a). Earlier in the decade, singing the 1992 patriotic song 'Dajem ti srce' ('I give you my heart'), Dragović had assimilated into her performance persona the maternal gender role inherent in Tudjman's conception of the nation (Senjković, 2002, p. 149), where a woman's primary duty was to bear children for the national collective and ensure the historical continuity of the Croat people. These associations may partly account for Dragović's position at the centre of the scandal.

At the height of this case, Alka Vuica (another invited performer) wrote an article for the Croatian weekly Nacional describing it as "the ultimate hypocrisy" to attack singers while Croatian entrepreneurs had re-established commercial (and sporting) relations with Serbia in all other respects (Djilas, 1999). Vuica, too, has been affected by her early willingness to perform in Serbia and Montenegro, and has arguably been more popular there than in her home country. This may be explained by her affection for overtly 'Balkan' musical elements and her frequent use of Serbian, Macedonian, Greek, and Turkish motifs and cover versions, aligning her with the "popular Balkan 
(counter) culture" described by Alexander Kiossev which celebrates such elements as positive signs of identification (Kiossev, 2002, pp. 184-5). ${ }^{5}$ This, and her level of cultural-political engagement (which is unusual on the Croatian popular music scene), marks her as distinct in a cultural environment suffused with ambivalence towards the concept of the Balkans. ${ }^{6}$

Yet little or no reaction was provoked by the Belgrade concerts a year later by Darko Rundek and the punk band KUD Idijoti (Grujičić, 2000). However, these artists belong to the rock discourse, where performers and consumers may define their product against both mass-market showbusiness and nationalistic chauvinism, ${ }^{7}$ while zabavna singers, far more dependent on mass-media channels, are far more vulnerable to their disapproval. Vuica's treatment of popular music as another aspect of commercial relations overlooks its cherished symbolic value as the cultural space of a national community, emphasized in the attempts made to establish certain genres as symbols of Croat, Serb, or Muslim identity (Laušević, 2000, pp. 293-4). Only by 2001-02 had Serbia and Montenegro become viewed as acceptable territory on which Croatian singers might perform, with the band Magazin undertaking a late-2001 Serbian tour and the singer Severina supporting a Djordje Balašević concert in Novi Sad (Goreta, 2002).

The significance of performances in Serbia continued to be understood in Croatia on a deeper level than the purely commercial, and a small number of artists, including Giuliano (a member of the far-right Croatian Party of Right (HSP)) and Mate Mišo Kovač (whose son died early in the war in Croatia), have refused outright to perform there (Marinović, 2001; Blažević, 2004). ${ }^{8}$ Nonetheless, Croatian performers continue 
to make their Serbian debuts, while a handful of singers, including Maja Šuput and Sandi Cenov, regularly participate at festivals in Budva and Herceg Novi which assemble singers from throughout ex-Yugoslavia. In March 2003, Croatian bands and singers such as Magazin, Severina, Boris Novković, Crvena jabuka, and Karma received awards at a Belgrade ceremony organized by Serbia's TV Pink, the first such event to assemble musicians from all the ex-Yugoslav states (Strukar, 2003b). The process has been assisted by the regularization of discographic activity: rather than being re-sold in pirate editions as in the 1990s, Croatian CDs and cassettes are now produced under licence by Serbian record companies, who frequently commit artists to promotional appearances. However, the amount of coverage this receives by the Croatian media is not commensurate with the performers' Serbian popularity. Recording and performance activity in Serbia itself no longer brings the opprobrium of the immediate post-Tudjman era, but still represents a parallel career for Croatian artists, with success in Serbia rarely presented as a matter of course in the public personae they offer to the domestic media.

The transnational reach of TV Pink, based in Serbia (where the channel has been strongly associated since the Milošević era with showbusiness-folk music, but also with the introduction of 1990 s music-video production values into Serbian music promotion (Kronja, 2001, pp. 42-5)) but available on satellite throughout the exYugoslav region, is one example of modern entertainment media's ability to frustrate the establishment of separate national cultural spaces. ${ }^{9}$ Another is the emergence of Internet sites providing legal or illegal access to pre-1991 and contemporary music, alongside transnationally-available Web pages which transmit publicity and gossip to an audience beyond national borders. This transnational consumption is restricted to 
users of the necessary technology. Yet, as opportunities for Internet access grow, they provide an increasingly significant channel for individuals to acquire transnational frames of reference towards popular culture, and compensate for the continued marginalization of other successor states' music in the mass-circulation media. The establishment of an MTV franchise for former Yugoslavia - branded as MTV Adria and initially available only in Slovenia, Croatia, and Bosnia-Herzegovina (Rašević, 2005 ) - represents a further phase of this development: the commercialization of an aspirational ideal of musical transnationalism, as if only so-called 'urban culture' (as opposed to 'turbofolk') could be described as transnational.

Like Serbia, Slovenia provides Croatian musicians with another potentially lucrative site of activity and media promotion, and in the 1990s represented the principal foreign market for the Croatian record industry. However, within the Slovenian context Croatian artists belong to the analytically fascinating framework of bivša domača (former domestic) music: Croatian, Serbian, Montenegrin, Bosnian, and Macedonian artists are aggregated into a conceptual whole which reinforces Slovenes' perception of distinctiveness from the other ex-Yugoslav peoples (Velikonja, 2002, p. 189), but also their consciousness of having in the past belonged to the Yugoslav community. ${ }^{10}$ Regardless of the extent to which Croatian identity is also defined against a nebulous 'Balkan' Other (Razsa and Lindstrom, 2004, p. 639), dominant and alternative Slovenian cultural models both include Croatian music in their own Balkan referent, leading to juxtapositions on radio broadcasts and compilation albums which would be highly unlikely on their performers' home market. Croatian music's symbolic role in Slovenia is illustrated by a scene from Maja Weiss's film 'Varuh meje' ('Guardian of the frontier', 2001), in which three girls on a canoeing trip cross 
to the Croatian bank of the Kupa/Kolpa river and chorus, far from coincidentally, a hit by the Croatian star Severina entitled 'Djevojka sa sela' - 'Village girl'.

Political and cultural factors have therefore restricted the commercial opportunities for Croatian artists. Once performances 'across the border' in Serbia and Montenegro resumed, they were first met with an implicit political acceptability test, and more recently with media indifference. From the perspective of Croatian performers, transnational prospects have certainly improved but still do not match the conditions of federal Yugoslavia's integrated market. Yet, in light of recent technological advances in satellite television and Internet communication, it might be argued that the entertainment market has undergone a qualitative transformation, and that a direct comparison between 1980s and contemporary music promotion is problematic.

\section{Serbian and Other Ex-Yugoslav Musical Activity in Croatia}

Even when most Croatian performers had become reconciled to viewing Serbia as another site of commercial operations, cultural flows in the opposite direction (Serbian performers in Croatia) remained contentious for longer. Before discussing this question in detail, it would be appropriate to consider activities by other republics' performers on the Croatian market: a handful of Slovenian schlager and dance artists have appeared on the Croatian market but left little impression, while the punk band Laibach retain their exclusive fan-base among a section of the urban rock audience, where their live performers' totalitarian references are understood as alternative art and as an opposite pole to the nationalist folk-rock which has emerged as a sub-genre of Croatian showbusiness (Glavan, 2002). Macedonian performers are 
all but absent from the Croatian scene, although Toše Proeski (already popular in Serbia) recorded an album for Croatia to capitalise on his appearance in the 2004 Eurovision Song Contest. The most active ex-Yugoslav performers in Croatia are unquestionably from Bosnia-Herzegovina, particularly the Bosniak singers Kemal Monteno, Dino Merlin, and Hari Mata Hari, ${ }^{11}$ and the Sarajevo band Zabranjeno pušenje. ${ }^{12}$ In contrast, Boris Režak, the first Bosnian Serb singer to be launched in Croatia, experienced contractual difficulties with his 2004 album and struggled to achieve the exposure of his Bosniak counterparts (Jadrijević-Tomas, 2004). Neither have Bosniak artists been accepted by the Croatian music industry as fully equal participants: the 2001 award of several Porins (the annual Croatian music prize) to the Merlin-Ivana Banfić hit 'Godinama' ('For years') prompted the ceremony’s organizers, headed by Paolo Sfeci, to amend the regulations so that prizes could only be won by Croatian citizens (Oremović, 2002).

Industry resistance to ex-Yugoslav performers appearing in Croatia on equal terms may on one level be understood as a commercially protectionist response. Such a tactic would aim to maintain the privileged treatment enjoyed by early-1990s Croatian artists when other republics' artists were withdrawn from the state media and Croatian singers became insulated from potential Serbian competition. Indeed, critiques of contemporary Croatian popular music frequently allege that the artificial advantage encouraged complacency among music producers and elevated mediocre talents into national stars (e.g. Gall, 2000). The early 1990s' climate has been vividly described by Dubravka Ugrešić as an element of the Tudjmanist "confiscation of memory" immediately noticed in everyday life (Ugrešić, 1998, p. 228). This represented a deliberate strategy by the ruling Croatian Democratic Union (HDZ) to re-align 
Croats" "symbolic universe" by removing from the historical and cultural spheres any reminder that Croatians had belonged to the national community of the former Yugoslav state: the political aim was to eliminate and stigmatize any allegiance other than to the regime which had secured Croatian independence (Zakošek, 2000, p. 110).

Purely commercial explanations therefore seem insufficient to account for the behaviour of industry professionals who had benefited throughout the 1990s from HDZ patronage. Both during and after the Tudjman era, opposition to performances in Croatia by Serbian artists was led by Sfeci, whose continued loyalty to Tudjmanist ideology is suggested by his statement regarding a parliamentary proposal to liberalize the work-permit regime that it would be "excellent news for all Yugoslavs and regionalists" (Gatarić \& Vuković, 2002). The Serbian musicians who 'returned' to Croatia under Tudjman were exclusively alternative rockers, including Rambo Amadeus (Vuković, 1998), and they first played in Istria and Rijeka, regions which have taken pride in multi-ethnicity and tolerance as a characteristic of their identity to the extent that their inhabitants define themselves partially against other, less tolerant, Croats (Kalapoš, 2002, p. 84). Zagreb, then the only other venue for Serbian performances, was still understood as more likely to provoke an adverse reaction, or even violence such as that against a 1996 Zabranjeno pušenje concert (Perić, 1996).

Croatian fans of Serbian artists often travelled to their Slovenian concerts instead, conferring on Slovenia a certain status as a liminal space for Croatian consumers of alternative cultural models. Djordje Balašević, among the most popular of them, was able to attract up to 10000 Croatians to his frequent concerts in Ljubljana, Maribor, and Portorož (Peršić, 2001). The prospect of a Balašević concert in Croatia only 
became conceivable after Tudjman's death, and occasioned intense speculation until the Slovenian supermarket chain Mercator assembled Balašević, Monteno, Oliver Dragojević (a respected Dalmatian zabavna singer) and Vlado Krušlin (of Slovenia) in December 2000 for two concerts in Sarajevo and Pula to mark new stores (Peršić, 2000). Balašević, whose pre-war popularity had been greatest in Croatia and Slovenia, performed his first solo concert in independent Croatia in June 2001 at the Pula Arena (Dobrila, 2001), and his first Zagreb concert in December 2002 (Pribačić \& Mamić, 2002).

Between 2000 and 2002, however, announcements that Balašević might perform in Croatia met with public disapproval from music industry representatives, from certain journalists, and from Homeland War veterans' organisations. ${ }^{13}$ These criticisms focused not only on Balašević's mid-1980s statements siding with Serbs against Kosovar Albanians (Jajčinović, 2002), but also on his early associations with the Yugoslav regime, particularly through his 1977 song 'Računajte na nas' ('Count on us') which declared the younger generation's loyalty to Tito and the heritage of the Partisan movement (Gugo, 2000). ${ }^{14}$ Yet Balašević's supporters too invested him with immense symbolic value, and anticipated his Croatian concerts "as a therapeutic séance and a symbolic beginning of a certain more civilized phase in Croatian-Serbian relations" (Gall, 2003b).

Typical in this respect were the words of Dražen Turina-Šajeta after the Mercator concert in Pula: Turina, himself a rock musician associated with Istria, ${ }^{15}$ took it as a sign that "things are slowly coming back to normal", took note of audience members moved to tears, and wished that Sfeci and other opponents of Balašević "were there 
too to cry as well at the disintegration of their ideal" (Turina, 2000). One transnationalism theorist mentions in passing that "persons cannot be Yugoslavs when Yugoslavia is gone" (Berezin, 2003, p. 11), but, on the contrary, Balašević's fan-base may provide the clearest example of post-Yugoslav musical transnationalism: they manifest not only the "common identity" underpinning many transnational networks but the participation in "socio-cultural [...] activities" with which such networks are formed and perpetuated (Vertovec, 2001, p. 573). Indeed, one anthropologist's exYugoslav informants experienced the former Yugoslavia as precisely "a cultural everyday space", composed of various collective rituals and cultural markers (Volčič, 2003, p. 15).

The major accusation against both Balašević and his fans was 'Yugo-nostalgia': in Croatian political life, this concept had served as a catch-all insult for any individual or idea which failed to correspond to Tudjmanist ideology and which was therefore assumed to self-evidently prefer the inimical previous regime (Ugrešić, 1998, p. 231). The Croatian nationalist project, politically striving to emphasize its distance from the ideological structure it had replaced, denied any distinction between political and individual/generational nostalgia, and consciously encroached into private memory to demand overt rejection of any positive memories of common Yugoslav life (Drakulić, 1996, p. 147).

Before his 2001 Pula concert, Balašević explicitly distinguished the "normal emotional human nostalgia" he was experiencing in Istria from the "nationalistic, territorial, or some Serbian or Yugoslav sense" with which a political nostalgic would mourn (Peršić, 2001). Similarly, Zlatko Gall, describing his own new-found 
appreciation of Balašević, wrote that such nostalgia was in no way subversive, "because emotional Yugo-nostalgia is completely legitimate [...] and because of the fundamental right to one's own and one's generation's past" (Gall, 2003b). In this emotional sense, Balašević certainly figures as an embodiment of nostalgia, and appreciation for his music even offers a potential symbolic resource through which individual Croatians can express their distaste for the nationalist right's apparent monopolization of definitions of Croatian identity.

Serbian artists' performances in Croatia have frequently become a site of conflict where the limits of the Croatian cultural space are contested, and these debates have demonstrated the persistence of 1990s ideology in what is commonly thought of as the 'post-Tudjman' era (since 2000). The return of Serbian musicians has highlighted issues of private memory versus publicly displayed allegiance, and prompted Croatians to interrogate the politicized concept of nostalgia. At the same time, the supposed post-Tudjman 'normalization' of Croatian cultural space suggests that one should re-examine the idea of transnationalism to also account for those whose displacement has been conceptual and temporal. The dynamics of the Balašević case, where the use of national-historical symbolism is particularly striking, invite a further study of the bases of musical preferences and Croatian identity.

\section{Transnational Cultural Flows as Symbolic Resources}

The coincidence of Balašević's 2001 concert with the summer of nationalist protests against General Mirko Norac's trial for war crimes (where the typical slogan on protestors' placards read "We are all Mirko Norac") led fans from Split to travel to 
Pula with banners and T-shirts reading "We are all Djordje Balašević" (Šarac \& Jelaca, 2001). ${ }^{16}$ Balašević has symbolic value on several grounds: his socio-musical position as a pop-rock singer who - apparently like much of his audience disapproves of the dominance of newly-composed folk music (Gordy, 1999, p. 107), his history of resistance to Milošević which has become implicit in his performance persona, and his pre-existing role in the Croatian right-wing imagination as a symbol of ideological nostalgia. Combined, these criteria led him to be understood as an explicit site of resistance to the Norac protests' right-revanchism, and also to the emerging 'patriotic showbusiness' genre emerging from the commercial opportunities of this political climate.

Indeed, a fascinating aspect of musical transnationalism in Croatia is how the figures of artists from other republics function as symbolic markers to define variant interpretations of Croatian identity, as may be observed in the case of an August 2003 concert by Momčilo Bajagić-Bajaga. Bajaga's first concert in post-war Croatia, in the Istrian town of Labin, had passed peacefully (Žužić, 2002), but this Split concert (already rescheduled to avoid a clash with a HDZ Youth pre-election concert ${ }^{17}$ ) was cut short when tear-gas canisters were thrown into the open-air venue (Petranović, 2003c).

As a major Croatian city situated close to the Dinaric region of Herzegovina and Dalmatinska zagora (sources of much rural-to-urban migration during socialist industrialization), Split had had particularly sharp experience of the tensions associated with Titoist Yugoslavia’s imperfect urbanization. Xavier Bougarel has pointed out that "forty years of accelerated modernization and urbanization have 
shifted the traditional antagonisms between [Yugoslav] town and countryside into the towns themselves" (Bougarel, 1999, p. 165). This discourse informs the anxieties of long-standing Split residents (including younger generations) in which Split and its familiar locales become public spaces contested by competing spatialized local identities. $^{18}$

Particular sensitivity had been aroused by the nationalist singer Marko Perković Thompson's celebrated, or notorious, Split concert in August 2002. Miro Kučić, for instance, had employed an essentialized conception of the Mediterranean on that occasion to underline how foreign such chauvinism was to Split's supposedly authentic nature, contrasting "the winds from the south" with "all their mildness and the beauty of the Mediterranean" against the recent arrival of "implacability, rudeness, [and] intolerance" carried on "the brutal, cold winds from Dinara" (Kučić, 2002). Accordingly, a Bajaga concert in Split took on added symbolic value as a reaffirmation of old-Split values against the nationalist Herzegovinan influx. Only two months earlier, in fact, one journalist from the Split daily Slobodna Dalmacija had expressed resentment of the fact that Serbian performers were avoiding Split "because it would be like pushing their hand into a hornet's nest when it doesn't want them there" (Ljubičić, 2003). The attack on Bajaga's concert was understood as also directed against "all those who - regardless of their place of birth - in Split today feel like the captives of other people's hate, xenophobia and primitivism" (Gall, 2003a). Coverage in the Rijeka-based Novi list, with a cosmopolitan urban readership, made exceptionally explicit use of the discourse when Zoran Krželj wrote that Split had thereby "once again stayed (or become) a village, that latest, backwoods Balkan [kind]" (Krželj, 2003). 
The heavy-handed police treatment of victims, according to Krželj, provoked the crowd on a night of symbolic resistance into chanting the Električni orgazam song 'Igra rokenrol cela Jugoslavija' ('All Yugoslavia is dancing rock-and-roll') (Krželj, 2003). ${ }^{19}$ This prompted further reflections on the Tudjmanist and post-Tudjman Croatian state as institutionally chauvinist, and "gave added strength to the impression that this city is lost for the civilized, for that so-called silent, civic majority" (Petranović, 2003b). Another commentary described the incident as "the logical consequence of a decade in which a parallel history of Split has been told with hate speech", mentioning the official blind eye turned to memorial masses for Ante Pavelić, a Split street named after the Ustaša ideologue Mile Budak, or Ustaša insignia displayed on the Riva (Gall, 2003a).

Bajaga's figure here represents different attitudes towards the desirable extent of Croatian relations with Serbia, but it also serves as a boundary-marker with which to construct and continually re-state a variety of identities within Croatian society. To a certain number of urban Croatians, Serbian pop-rock and alternative performers exist as a cultural resource with which to distance themselves from musical genres they associate with the ruralization (and Herzegovinization) of Croatian city space, summed up by Boris Dežulović's comment that:

The new Split audience has been recruited in large part from Herzegovina, from where there have come in the last ten years tens of thousands of new Splićani [inhabitants of Split] to whom narodnjaci [newly-composed folk songs] are somewhat closer than Oliver Dragojević [a renowned singer from the city]. (Dežulović 2002) 
The Bajaga case demonstrates that these Croatians' established urban values may be expressed through a transnational identification as a mark of tolerance. Yet, the transnational consumption of another musical genre, newly-composed folk music, is associated in this discourse with the supposedly rural-in-urban population itself, providing an example of how identities can be shaped and re-asserted through expressing value judgements in social interaction (see Jenkins, 1996, p. 4). The

judgements of similarity and difference on which this method of identity-formation is founded depend on a community's "symbolic repertoire", with reference to which its members "suppose themselves to be more like each other than like the members of other communities" (Cohen, 1985, p. 21), and to which musical products may make a significant contribution (Edensor, 2002, p. 25). Urban-Croatian insecurity concerning rural-to-urban migration demands that Serbian folk singers' reception there should be considered separately from that of pop-rock stars.

\section{The Transnationalism of Folk: Serbia-Croatia-Herzegovina}

Unlike the cases discussed above, the Zagreb concert in November 2004 of Željko Joksimović, the first large-scale performance given by a Serbian performer associated in Croatia with folk (Dervoz 2004b) ${ }^{20}$ attracted neither violent incidents nor antagonistic newspaper reports detailing the singer's politically-connected past. ${ }^{21}$ Coverage described a "euphoric", mainly young audience (Mamić, 2004), with the only discordant note being struck by the Slobodna Dalmacija reporter who employed an all too telling metaphor in concluding that the Serbian star was hoping to, "after the other neighbours, subjugate the Croatian market too" (Marušić, 2004). Joksimović's 
arrival may represent a particularly significant development, since Serbian folk music has typically been marginalized - although far from absent - on the Croatian musical market.

Serbian folk artists were not promoted through the Croatian broadcast media (although TV Pink and the Karić Brothers channel are available to Croatian satelliteTV subscribers), although they were occasionally profiled in print (e.g. Strukar, 2003a). Their recordings were not sold in mainstream outlets, and were mainly available through pirate vendors. Vesna Zmijanac estimated that some of her records had sold up to 40000 copies in Croatia in pirate editions (Šćepanović, 2003), ${ }^{22}$ while a 1995 investigation had suggested similar figures for Zmijanac, Dragana Mirković, and Lepa Brena and noted that "even the hated Ceca" (the widow of the assassinated paramilitary commander Željko Ražnatović-Arkan) had sold 18000 pirate cassettes (Djilas, 1996). Such figures, in a market where sales of 10000 copies could be a rarity (Gall, 2000), were of some anxiety to the Croatian music industry as part of its concern with piracy in general. Folk concerts predominantly took place in small clubs and bars, particularly the Ludnica and Od sumraka do zore/Pasha discotheques in Zagreb, Oks in Osijek, and several venues in Split. Even in 1990, venues in Zagreb playing newly-composed folk music had already enjoyed underground popularity, thanks to their appeal as a culturally illicit form of entertainment (Rasmussen, 2002, pp. 184-5), and this again appears to be the case in post-Tudjman Croatia.

However, Serbian folk singers' concerts normally occurred below the threshold of media attention, apart from a spring 2002 edition of the talk-show Latinica which dealt with the subject and featured the Serbian folk singer Miroslav Ilić on his first 
post-war tour of Croatia (Stanivuković, 2002). A November 2004 survey for the Croatian daily Večernji list revealed the number of small-scale appearances by artists including Ilić, Neda Ukraden, and Dragan Kojić-Keba, with Zmijanac accumulating the most performances (Dervoz, 2004a). Ceca Ražnatović's associations with Milošević, and with the events surrounding the death in 2003 of the Serbian prime minister Zoran Djindjić (Greenberg, 2006, p. 142), continue to make her perceived as unsuitable to perform in Croatia. Nonetheless, she too enjoys an underground following, supposedly so much so that the image of nationalist Croats hypocritically blasting Ceca's music from their cars has become a cliché of Croatian discourse (Ljubičić, 2003; Gall, 2002b; Petranović, 2003a). Nonetheless, this image's very frequency suggests that it may be underpinned by symbolically-based social value judgements - which frown upon such overtly-displayed nationalism by aligning it with this 'most Serbian', most Othered, Serbian performer.

Joksimović, however, transcended this framework after attaining high levels of recognition among the Croatian audience with his second place in the 2004 Eurovision Song Contest - helped by maximum points from the Croatian public 'televote'. The entirely unexpected result occasioned much comment both in Croatia and in the Serbian press (Trajković, 2004), and paved the way for Joksimović's Zagreb performance, ${ }^{23}$ when one headline observed that he had "opened the borders to ex-Yu music" (Mikac, 2004). In 2004, it remained too early to assess whether Joksimović had done so. Concerts by Serbian artists including Bajaga, Balašević, Zdravko Čolić, Dragana Mirković, and Indira Radić took place thereafter in Croatia amid little media comment, suggesting that they were no longer a notorious novelty especially when they were by pop-rock or zabavna stars rather than folk performers. 
Even the appearance of Lepa Brena, the most emblematic newly-composed folk singer of socialist Yugoslavia (Ugrešić, 1998, p. 231), on Alka Vuica’s television talk-show Jedan na jedan in early 2005 failed to ignite the reactions which surrounded Balašević's return to Croatia. Yet the same could not be said for Petar Vlahov's January 2005 interview with Ceca Ražnatović, which provoked so many complaints that the show was never even broadcast (Mamić, 2005): apparently Ceca's unsuitability extended even to representing her in the discourse of showbusiness personality rather than in that of wartime and political guilt. In this instance, at least, the boundaries of the Croatian cultural space are being consistently marked by excluding Ražnatović and her ethno-political connotations.

Another transnational musical product also figures strongly in the Croatian symbolic repertoire: music performed by certain Bosnian Croat singers, and especially those who have associated themselves with the post-Tudjman sub-genre of patrioticallythemed showbusiness. It is debatable whether this interaction should even be treated as transnationalism: although the flow takes place across a political border, these artists would emphasize the cultural unity of their Croatian and Herzegovinan-Croat audience and make the case that the border is artificial. Performers of Croatian and Bosnian-Croat origin have equal standing in this emerging genre, as their music also indicates: e.g., that of Marko Perković Thompson (from Čavoglave in Croatia) recognizes Herzegovina (or 'Herceg-Bosna') as an integral component of the Croatian landscape. In 2002, the Croatian Democratic Union of Bosnia-Herzegovina (HDZ$\mathrm{BiH})$ engaged Thompson for their climactic election rallies, and even adopted a line from his song 'E, moj narode' ('O, my people') as one of their slogans (Bubalo, $2002) .^{24}$ 
Bosnian Croats who have entered the Croatian discographic market from this background include Tiho Orlić (from Mostar) and Mate Bulić, a folk singer among the most popular artists in the Croat diaspora (Senjković \& Dukić, 2005, p. 50). The chauvinistic attitudes which some of them continue to express on- and off-stage remind one that transnational activity is by no means necessarily associated with reconciliation between the successor states. ${ }^{25}$ Another prominent Bosnian Croat singer, Ivan Mikulić, performed zabavna music but belonged to patriotic showbusiness by participating in right-wing events and concerts. ${ }^{26}$ When Mikulić won the 2004 Dora festival and the opportunity to perform at the Eurovision Song Contest, a journalist from Novi list (a Rijeka daily) concluded with disapproval that "Ivan Mikulić [...] has quickly acquired the nickname in Rijeka of a soft Marko Perković Thompson" (Brajčić, 2004). As became evident in the discussions of local identity in Split, the discourses surrounding Thompson himself are an even more acute example of many urban Croats' ambivalence to cultural markers associated with the Dinara region transected by the Croatian-Bosnian border.

Thompson has consistently embraced 'Dinaric' musical signifiers, and indeed his style has become paradoxically characterised by the Macedonian-style 7/8 beat first incorporated into rock music by Goran Bregović's Bijelo dugme (Gall, 2002a). Niko Bete's song 'Mirko Norac', dedicated to the general indicted for war crimes, is likewise set to the $7 / 8$ rhythm. ${ }^{27}$ Following the violence against Zabranjeno pušenje in 1996, Paolo Sfeci had stated that the incident had "only shown that there is no place for the eastern [istočnjački] melos in Croatia!" (Perić, 1996). In some right-wing imaginaries, however, such antagonism can be waived to accommodate these hyper- 
patriotic artists - or, as Zlatko Gall memorably commented, "what if his [Thompson's] musical expression verges on Balkan turbofolk, if he's a turbo-Croat?" (Gall, 2002b).

Anthony Cohen speculates that "structural forms" appropriated from elsewhere may still "become new vehicles for the expressions of indigenous meanings", and even “for the reassertion and symbolic expression of the community's boundaries" (Cohen, 1985, p. 37), and this would appear to hold true for Thompson and Bete. However, the suffusion of anti-patriotic-showbusiness discourses with a wider Croatian ambivalence towards newly-composed folk music and so-called 'eastern' musical elements leads one to reflect on a deeper level at which transnational flows have operated in the post-Yugoslav environment: the supposed influence of Serbian showbusiness-folk on Croatian musical production.

\section{Showbusiness Folk Music as a Transnational Form}

Serbian performers, as noted in the first sections of this paper, were subject to hostility and setbacks in 1990s Croatia: yet even then, the popularity of newlycomposed folk music (NCFM) could be said to have been sustained, or even increased. In the Yugoslav era, this genre had mainly been associated with Serbia and Bosnia (Rasmussen, 2002, p. 95). During the 1990s, however, certain techniques from NCFM became apparent in Croatian pop production, a development which was viewed by certain professional critics and musicians as transgressing the boundaries of musically-expressed Croatian identity. The approaches taken towards folkinfluenced zabavna music and its apparent 'eastern melos' indicate how the 
transnational phenomenon of showbusiness-folk was incorporated or denied as an element of Croatian cultural space.

During the 1980s, the use of electronic instrumentation and pop-style promotion in newly-composed folk music had culminated in the repertoire of performers such as Lepa Brena. Brena based herself in Serbia after the disintegration of Yugoslavia and, along with her colleagues, was then excluded from the Croatian market. One Croatian ethnomusicologist takes pains to stress that NCFM was not an established Croatian genre before 1991 (or, implicitly, afterwards), emphasizing instead Croatia’s affinity to zabavna music, tamburica-pop, ${ }^{28}$ and "Anglo-American-style pop and rock" (Ceribašić, 2000, pp. 227-8). Yet, even though NCFM was mainly released by other republics' record companies, a Croatian audience still existed, and individual Croatian producers had begun to experiment with the so-called 'eastern melos' even in the 1980s. Tonči Huljić and his band Magazin (not least on their mid-1980s hit 'Istambul'); Doris Dragović recorded several songs for her 1989 album 'Budi se dan' which employed NCFM's characteristic tremolo vocal technique; and Rajko Dujmić, producer of the Novi fosili group, at the time viewed his collaboration with Neda Ukraden (a Bosnian Serb singer from Sarajevo) as "a pioneering attempt to introduce the folk sound into pop music" (Luković, 1989, p. 277).

Thus the Croatian fusion of zabavna schlager with NCFM elements was not, as some critiques imply, concocted from nothing after Croatia's independence. Nonetheless, it gathered greater pace in the 1990s, when it was proverbially epitomised by Huljić, Magazin, and the clients of his record-label Tonika. Other performers, such as Severina or Ivana Banfić, came to include increasing proportions of this music in their 
repertoires, and the genre in turn fused with others, especially with dance in the work of the groups Colonia and Karma. ${ }^{29}$ These songs incorporate folk-style rhythms and vocal ululation while retaining some degree of zabavna orchestration or melody, while the synthesized accordion flourishes common to the Serbian variant are not present in Croatian repertoires. Their lyrics, meanwhile, operate like those of Serbian/Bosnian NCFM by relying on "clichéd syntagms and rhymes" and melodramatic situations which, combined with repetitive melodies, work to make them as memorable as possible (Dragićević-Šešić, 1994, pp. 205-6) or to convey images of romantic and family life (Čolović, 1985, pp. 185-6).

The most frequent Croatian critique of this trend directly connects it with the early 1990s, arguing that the removal of Serbian cultural products from the media created a commercial opportunity to fulfil consumers' demands by providing a new stable of artists whose Croatianness was not in question, and who would perform "pseudofolkloric schlager" to replace "its 'newly-composed' aesthetic eastern relative" (Gall, 2000). An extreme example of this ambivalence is given in an anecdote retold by Dubravka Ugrešić, who writes that an unknown Croatian female singer re-recorded a number of songs by Neda Ukraden (by then living in Serbia) - ostensibly to return the work of Ukraden's Croatian songwriters to "the corpus of Croatian pop” (Ugrešić, 1998, pp. 140-1), but perhaps also as another attempt to turn Croatians' ambiguous relationship with narodnjaci to commercial advantage.

However, the pre-1991 origins of Croatian narodnjaci invite a deeper examination of Croatian discourses, where Serbian 'turbofolk' can operate as a convenient benchmark against which to judge the 'cheapest' Croatian specimens. Serbian folk 
music itself is usually abbreviated into the figures of Ceca Ražnatović (made all the more suitable to represent the Other by virtue of her marriage to Željko RažnatovićArkan) ${ }^{30}$ or Lepa Brena: other showbusiness-folk stars, such as Jelena Karleuša or Dragana Mirković, do not figure in this symbolism. The strength of Ceca's associations with the Milošević regime, and of Brena's with the previous one, suggest that the decisive indicators in these value-judgements are non-musical - and that a Croatian cultural identity is being implicitly defined with reference to its supposed political opposites.

Nonetheless, Croatian narodnjaci (folk-type songs) are less likely to be criticized as 'srpski' ('Serb’) or 'jugoslovenski’ ('Yugoslav') than as 'istočnjački’ ('Eastern). This framework is rooted in the 'symbolic geography' identified by Milica Bakić-Hayden and Robert Hayden, where a nation's particular Other is constructed as non-European and 'Balkan' (Bakić-Hayden \& Hayden, 1992, p. 10; see Razsa and Lindstrom, 2004). The music critic of the Croatian daily Jutarnji list provided a striking example of this when commenting on a rumoured collaboration between Željko Joksimović and Ivana Banfić: Croatian showbusiness had, apparently, "been 'Serbianised' [posrbila], i.e. Turkicised [poturčila], a long time ago" even without that duet, and it was impossible to think that "Colonia, Thompson, [Miroslav] Škoro, Mate Bulić or Magazin are autochthonous Croatian products"; continuing the eastern-related symbolism, the clients of Tonči Huljić were described as renegades or "poturice", a word connoting Christian converts to Islam during the wars with the Ottoman Empire (Dragaš, 2004). Even when these allusions are employed as a knowing metaphor, the inherent symbolism remains highly significant. 
If international popular music styles in Croatia enable a sense of belonging to a global community (Kalapoš, 2002, p. 90), much of the unease surrounding the folk-based turn in Croatian music may involve a perception that it connects national culture to a more limited 'Balkan' community and to the ruralized-urban culture from which NCFM originated (Rasmussen, 2002, p. 200). Describing Serbian music, Eric Gordy understands the folk element of Serbian 'turbofolk' as primarily a "sociological”" category, where folk is constructed according to "other basic social oppositions: the urban against the rural and semiurban publics, and as a parallel, rock and roll against folk” (Gordy, 1999, pp. 135-6). In the same vein, Milena Dragićević-Šešić describes NCFM as enabling "a person with a traditional structure of thought and feeling [who] otherwise feels alienated and rejected" in the city to relieve their alienation with a musical product which corresponds to that familiar, traditional structure despite its modern or even exotic orchestration (Dragićević-Šešić 1994, p. 57). If NCFM provides a means for its listeners to escape full submission to the values of the city and its opponents certainly appear to understand it thus - then unease about its popularity may ultimately imply anxiety for the universalism, or otherwise, of individual consciousness in Croatian society.

In terms of politics, Dunja Rihtman-Auguštin considered that the use of nationalism as a form of political mobilization in the 1980s had particular resonance for "the semiurban suburbs [and...] newly-settled residents of the centre", for whom the nation provided a framework which could connect a new and somewhat alien city identity to a more familiar local identity (Rihtman-Auguštin, 2000, pp. 29-30). If it could be established that both musical producers and nationalist politicians were striving for the same target audience, there would be even more reason to investigate any 
harmony of thought or action between the music industry and political ideology in Croatia.

In terms of showbusiness, meanwhile, the argument that Croatian folk-type music only exists as a substitute for an authentic Serbian product has become even harder to substantiate now that younger stars have emerged whose target audience might not even have been born when the war in Croatia finished. Instead, narodnjaci appear to have an established place in Croatian popular music, as shown by the career of Severina Vučković, who became Croatia's most prominent female singer in precisely this period. Severina has received criticism for performing little but a "sequence of orthodox eastern [istočnjački] turbofolk themes" which position her as "a Lijepa Brijena", i.e. an acceptably Croatian version of Lepa Brena (Gall, 2001b). Brena and Severina emerged under quite different social circumstances, but both artists have resorted to similar methods in their use of multiple stage personae, ${ }^{31}$ a technique which has taken Severina from her 1993 album 'Dalmatinka' ('Dalmatian woman'), to her 1998 album 'Djevojka sa sela' ('Village girl'), and finally to her late-2004 single 'Hrvatica' ('Croatian woman'). ${ }^{32}$ Positively or negatively, Brena exists as a cultural pattern within which Severina could be understood inside and outside Croatia, even if she does not deliberately strive to conform to it.

Although the national narratives of the former Yugoslav communities have altered since the late 1980s, musical preferences have to a certain degree endured, and the market has responded accordingly. While the 1990s ideologues of independent Croatia officially endeavoured to distance the Croatian people from their Balkan neighbours, a state-favoured music industry nonetheless allowed performers of the 
transnational genre of narodnjaci to flourish to such an extent that, since Severina's high-profile Croatian and Bosnian concert tour in 2001-2, Croatia has essentially reexported a folk-pop star to all the other successor states as one of the most iconic singers on the territory of former Yugoslavia.

\section{Conclusion}

Now that artists such as Joksimović and Severina understand their audience in transnational terms, it might be tempting to conclude that the popular music market of former Yugoslavia is turning full circle and repairing the trans-republican linkages interrupted by the consequences of disintegration. Anti-nationalist dissent has emphasized the persistence of personal memory throughout this process, implying the extent of resistance in the private sphere even when nationalising projects are complied with in public (e.g. Drakulić, 1996) and suggesting in passing that popular music is intimately related to this sphere of the everyday (Ugrešić, 1998, p. 133). ${ }^{33}$ From this perspective, it might be comforting to interpret the recent rapid growth of transnational consumption and production in ex-Yugoslav popular music as the repair of formerly-shared experiences. Yet this would overlook the effect of Croatia's 1990s severance from Yugoslav cultural space, when Croatian musicians and consumers nonetheless confirmed their affinity for the transnational form of newly-composed folk music. In the late 1980s, Croatia's most successful musical exports to the rest of Yugoslavia had predominantly been zabavna performers such as Dragojević, Dragović, Novi fosili, Magazin, and Tereza Kesovija (Dragićević-Šešić, 1994, p. 106). These personalities have retained their popularity, but they have been joined (even outstripped?) by performers whose music approaches showbusiness-folk. 
At the same time, music from the Yugoslav period which suddenly became transnational has also taken on new meanings in the identity narratives of younger generations, where the "Yugoslav imaginary" is indivisible from the "unique, culturally specific brand of rock'n'roll" produced in socialist Yugoslavia and the bands of the 1980s rock scene are conceptualised as "the cultural links between different [Yugoslav] nations" (Volčič, forthcoming, pp. 17-18). This orientation does not hold true for all youth, and, indeed, the 'moral panics' which have ensued on the topic of Croatian teenagers listening to (Serbian) newly-composed folk or (Croatian) patriotic music (Perasović, 2006, p. 5) suggest that the symbolic opposition of 'folk' and 'rock' (Prica, 1991; Gordy, 1999) has persisted into post-Yugoslav youth cultures. In the case of 1980s Yugoslav rock, it is uncertain how often its consumption may serve as a generational mark of difference in cases where adolescents' parents are of an age to have participated in the 'new wave' scene themselves. Yet, as the cases of Balašević's and Bajaga's return to Croatia indicate, it certainly appears to serve as a social mark of difference which distinguishes one's own group from others of a perceived less-than-urban background - who are imagined as consumers of transnational folk music.

In 2005 and 2006, the publicising and commodification of transnational products from the Yugoslav period reached a state where "the Yugoslav past" became "one more free-floating signifier of consumer desire", as in the widely mediatised reunion of the iconic ex-Yugoslav band Bijelo dugme (Volčič, forthcoming, p. 4), and new musical products could be devised which played with those transnational signifiers in a “recycling” of past identities (Mikić, 2006, pp. 6-7). Simultaneously, post-Yugoslav 
transnational music penetrated ex-domestic markets with ever more visibility, assisted by the cross-border reach of the Internet and satellite television: MTV Adria promoting 'urban' music and TV Pink transmitting showbusiness-folk. However, these developments depended on the negotiation of political and cultural obstacles which had taken place between 1999 and 2004, a time of reconstruction and recontextualisation in ex-Yugoslav cultural spaces. Moreover, the tensions of identity observed during this earlier period were by no means resolved, but continued to affect the reception of transnational music despite the opening-up of national media spaces.

\footnotetext{
${ }^{1}$ Some research for this paper was enabled by the Arts and Humanities Research Council. I am grateful to Ana Dević, Jasna Dragović-Soso, Denisa Kostovicova,
} Jelena Obradović, Obrad Savić, Claire Wilkinson, Daphne Winland, and anonymous reviewers for comments on earlier versions of this paper.

${ }^{2}$ Schlager is a central and northern European style of popular music typically featuring romantic and sentimental lyrical themes and orchestral or electric-guitar musical arrangements. Ex-Yugoslav zabavna (light-entertainment) music also includes elements of Italian canzonetta, and in stricter senses excludes so-called 'newly-composed folk music', which is classified as folk or narodna.

${ }^{3}$ Varešanović and Džinović are Bosnian performers; Nikolić is Serbian.

${ }^{4}$ Sfeci was formerly a member of the rock group Boa.

${ }^{5}$ Emblematic of Vuica's repertoire, also including versions of songs by Bijelo dugme and Momčilo Bajagić-Bajaga, is her 2004 song 'Bosna' ('Bosnia'), a duet with the folk singer Halid Bešlić and unashamedly nostalgic for 1980s multi-ethnic Sarajevo.

${ }^{6}$ See Razsa and Lindstrom, 2004.

7 "Rock discourse": see Frith, 1996, p. 67. 
${ }^{8}$ The fact that Oliver Dragojević, an iconic Dalmatian zabavna singer, has not yet performed in Serbia has also been interpreted in the Croatian and Serbian media as refusal to do so. If this is the case, his refusal has been less public than Giuliano's or Kovač's.

${ }^{9}$ TV Pink's owner, Željko Mitrović, also owns the Serbian company City Records, which releases the largest amount of Croatian music under licence (Globus, 2005). ${ }^{10}$ Is the Slovene nation here permanently defined not by its separateness, but by the act of having separated?

${ }^{11}$ The most successful releases by mainstream Bosniak artists are often duets with Croatian female singers, such as Monteno/Danijela Martinović (2001), Leo/Severina (2000), Merlin/Ivana Banfić (2000), Merlin/Nina Badrić (2004), and Hari Mata Hari/Banfić (2003): almost suggesting that they are most commercially acceptable when symbolically 'vouched for' by a Croatian partner.

${ }^{12}$ Zabranjeno pušenje split during the war in Bosnia, leading to Bosnian-based and Serbian-based versions of the band (the Serbian-based version, founded by Nele Karajlić) is also known as the No Smoking Orchestra). The band active in Croatia is the Bosnian branch.

${ }^{13}$ E.g., the veterans who protested against Balašević using the Croatian National Theatre for a concert in Osijek (Stojčić, 2002)

${ }^{14}$ In 2002, Balašević claimed that he stopped performing 'Računajte na nas' ('Count on us') in 1983 or 1984 after he was personally required to sing it at a state celebration by the federal interior minister Stane Dolanc (Stanić, 2002).

${ }^{15}$ On Turina's relationship to Istrian and Croatian identities, see Kalapoš, 2002, pp. 68-74.

${ }^{16}$ Split had been the site of the largest pro-Norac demonstrations. 
${ }^{17}$ Apparently at Bajaga's insistence.

${ }^{18}$ Similar dynamics in Belgrade have been described by Eric Gordy (1999, pp. 105-8) and Zala Volčić (2005, pp. 648-50). On spatialized identity in general, see Edensor, 2002, p. 48.

${ }^{19}$ In Zala Volčič’s interviews with young Slovenian and Macedonian intellectuals on the memory of Yugoslavia, "almost all" her informants recalled and sang this song (Volčič, forthcoming, p. 17).

${ }^{20}$ 5,000-6,500 people attended Zagreb's Dom sportova. Joksimović is marketed in Serbia as a singer of folk, not pop, music; in Croatia, however, he is received as another folk singer.

${ }^{21}$ Despite one journalist's attempt in May to call scandalous attention to Joksimović's statement to TV Pink that he would "conquer Constantinople" at Eurovision (Strukar, 2004).

${ }^{22}$ The figure may have related to pre-war releases.

${ }^{23}$ In the meantime, Joksimović had also become the first Serbian artist to submit a song (performed by Alka Vuica) to Croatia’s Splitski festival.

${ }^{24}$ The party had previously relied on zabavna singer Tereza Kesovija and rock singer Jura Stublić. In 2002, Ivana Banfić, Mišo Kovač and Crvena jabuka were engaged for NS-RB election meetings, while Vesna Zmijanac and Miroslav Ilić performed for Bosnian Serb parties.

${ }^{25}$ The ex-Yugoslav diaspora provides other examples of transnationalism without reconciliation - such as the YugoUK Internet forum which carries pro-Milošević, anti-Croatian newsfeeds on its front page (http://www.yugouk.co.uk [accessed 29 May 2006]), but is still happy to promote Croatian performers including Magazin and 
Darko Rundek in its concert listings. On ex-Yugoslav popular music and identity among migrants in Vienna, see Fischer, 2005, pp. 67-71.

${ }^{26}$ These include performing at the 2003 Sinj Alka (jousting festival), and appearing in a video honouring Tudjman during the overture at Thompson's 2002 concerts (Paštar, 2003; Gospodnetić, 2002).

${ }^{27}$ Since the song's release, Norac has been convicted of war crimes by a Croatian court.

${ }^{28}$ The tamburica is a stringed instrument from Slavonia.

${ }^{29}$ In Serbia, 'turbo folk' likewise came to overlap with dance (Kronja, 2001, pp. 667).

${ }^{30}$ For instance, Krželj, 2002; Gall, 2002b; Dežulović, 2002; Vodopija, 2004; Pavičić, 2005.

${ }^{31}$ See Dragićević-Šešić, 1994, pp. 146-7 on Brena.

${ }^{32}$ Compare Brena's 'Jugoslovenka' ('Yugoslav woman'). In fact, the Croatian performer most open to comparisons with Brena in this period was perhaps Maja Šuput, who made great use of Brena's characteristic male backing-vocals and her typical lyrical themes of joy and entertainment - and was criticised on these grounds from a 'Balkanist' perspective (Strukar \& Mamić 2003).

${ }^{33}$ On ethnological approaches to the reproduction of national (etc.) symbols in everyday life, see Kalapoš, 2002, pp. 11-12. 


\section{References}

Bakić-Hayden, M, \& R. M. Hayden. (1992) Orientalist variations on the theme "Balkans": symbolic geography in recent Yugoslav cultural politics, Slavic Review 51(1), pp. 1-15.

Berezin, M. (2003) Europe Without Borders: Remapping Territory, Citizenship, and Identity in a Transnational Age (Baltimore, MY: Johns Hopkins University Press).

Blažević, D. (2004) Pjevat ću besplatno Jadranki Kosor u predsjedničkoj kampanji, Slobodna Dalmacija, 20 June.

Bougarel, X. (1999) Yugoslav wars: the "revenge of the countryside" between sociological reality and nationalist myth, East European Quarterly 33(2), pp. 157-75.

Brajčić, S. (2004) Mikulić za razliku od većine bar zna pjevati, Novi list, 16 March.

Bubalo, R. (2002) U predizbornu utrku u BiH uključene brojne zvijezde hrvatske i srpske glazbene estrade, Večernji list, 21 September.

Ceribašić, N. (2000) Defining women and men in the context of war: images in Croatian popular music in the 1990s, in: P. Moisala \& B. Diamond (Ed.), Music and Gender (Urbana \& Chicago, IL: University of Illinois Press).

Cohen, A. P. (1985) The Symbolic Construction of Community (London \& New York: Routledge).

Čolović, I. (1985) Divlja književnost: etnolingvističko proučavanje paraliterature (Belgrade: Nolit).

Dervoz, L. (2004a) Srpski folk u Lijepoj naši, Večernji list, 4 October.

Dervoz, L. (2004b) Željko Joksimović bacio Zagreb u trans, Večernji list, 4 November.

Dežulović, B. (2002) Kraljica Marakane u Slobodnoj Dalmaciji, Dani, 5 July.

Djilas, M. (1996) Daj nešto za plakanje, NIN, 20 September. 
Djilas, M. (1999) Pjevači na granici, AIM, 22 December, available online at: http://www.aimpress.ch/dyn/pubs/archive/data/199912/91222-008-pubs-zag.htm [accessed 30 July 2004].

Dobrila, D (2001) Kao stari gladijator vraćam se u Arenu, Novi list, 18 June.

Dragaš, A. (2004) "Balkanizacija" hrvatske estrade, Jutarnji list, 16 July.

Dragićević-Šešić, M. (1994) Neofolk kultura: publika i njene zvezde (Sremski Karlovci \& Novi Sad: Izdavačka knjižarnica Zorana Stojanovića).

Drakulić, S. (1996) Café Europa: Life after Communism (London: Abacus).

Edensor, T. (2002) National Identity, Popular Culture and Everyday Life (Oxford \& New York: Berg).

Faist, T. (2000) Transnationalization in international migration: implications for the study of citizenship and culture, Ethnic and Racial Studies 23(2), pp. 189-222.

Fischer, W. (2005) A polyphony of belongings: (turbo) folk, power, and migrants, in: T. Marković \& V. Mikić (Ed.), Music and Networking (Belgrade: Signature), pp. 58-71.

Fiske, J. (1987) Television Culture (London \& New York: Routledge).

Frith, S. (1996) Performing Rites: On the Value of Popular Music (Cambridge: Cambridge University Press).

Gajić, B. (2004) U senci Severine, Ilustrovana Politika, 12 June.

Gall, Z. (2000) Nadgrobne ploče, Feral tribune 755.

Gall, Z. (2001a) Ljuta trava zaborava, Slobodna Dalmacija, 29 November.

Gall, Z. (2001b) Prianja baš uz svaku podlogu, Slobodna Dalmacija, 3 December.

Gall, Z. (2002a) Neću u Čavoglave, nisam ni prije!, Slobodna Dalmacija, 28 August.

Gall, Z. (2002b) Thompson: Hrvatska Ceca, Slobodna Dalmacija, 21 September.

Gall, Z. (2003a) Pljuni i zaplači, moja Croatio, Slobodna Dalmacija, 13 August.

Gall, Z. (2003b) 'Povrat Djoletove imovine', Slobodna Dalmacija, 5 February. 
Gatarić, Lj., \& Ž. Vuković (2002) Strani pjevači i strojari 30 dana bez radne dozvole, Večernji list, 10 June.

Glavan, D. (2002) Kratka povijest ekstremne rock-ikonografije, Večernji list, 12 October.

Globus (2005) Prvi čovjek TV Pinka - Željko Mitrović, 7 January.

Gordy, E. D. (1999) The Culture of Power in Serbia: Nationalism and the Destruction of Alternatives (University Park, PA: Pennsylvania State University Press).

Gospodnetić, L. (2002) Thompson i Hrvati, Slobodna Dalmacija, 17 September.

Greenberg, J. (2006) “Goodbye Serbian Kennedy”: Zoran Đinđić and the new democratic masculinity in Serbia, East European Politics and Societies 20(1), pp. $126-51$.

Grujičić, N. (2000) Povlašćeni odmetnici, Vreme, 14 December.

Gugo, A. (2000) Djoka, ne računaj na nas!, Slobodna Dalmacija, 30 July.

Hannerz, U. (1996) Transnational Connections: Culture, People, Places (London \& New York: Routledge).

Jackson, P., P. Crang, \& C. Dwyer. (2004) The spaces of transnationality, in: P. Jackson, P. Crang, \& C. Dwyer (Eds), Transnational Spaces (London \& New York: Routledge).

Jadrijević-Tomas, S. (2004) Nisu ga htjeli Croatia Records ni Radijski festival, Slobodna Dalmacija, 5 July.

Jajčinović, M. (2002) Tko to tamo gostuje, Večernji list, 22 December.

Jenkins, R. (1996) Social Identity (London: Routledge).

Kalapoš, S. (2002) Rock po istrijanski: o popularnoj kulturi, regiji i identiteta (Zagreb: Naklada Jesenski i Turk). 
Kellner, D. (1995) Media Culture: Cultural Studies, Identity and Politics between the Modern and the Postmodern (London \& New York: Routledge).

Kiossev, A. (2002) The dark intimacy: maps, identities, acts of identification', in: D. Bjelić \& O. Savić (Eds), Balkan as Metaphor: Between Globalisation and Fragmentation (London: The MIT Press).

Kronja, I. (2001) Smrtonosni sjaj: masovna psihologija i estetika turbo-folka (Belgrade: Tehnokratia).

Krželj, Z. (2002) Norac i Gotovina nisu došli, ali svi ostali jesu!, Novi list, 17 September.

Krželj, Z. (2003) Bajagin koncert prekinut bombama sa suzavcem, Novi list, 13 August.

Kučić, M. (2002) Surovi vjetar s Dinare, Slobodna Dalmacija, 8 October.

Lacko, R. (1999) Na poziv don Branka Sbutege pjevat ću u Herceg Novom, Večernji list, 16 December.

Laušević, M. (2000) Some aspects of music and politics in Bosnia, in: J. M. Halpern \& D. A. Kideckel (Ed.), Neighbours at War: Anthropological Perspectives on Yugoslav Ethnicity, Culture and History (University Park, PA: Pennsylvania State University Press).

Ljubičić, S. (2003) Srpski pjevači boje se Splita, Slobodna Dalmacija, 2 June.

Luković, P. (1989) Bolja prošlost: prizori iz muzičkog života Jugoslavije (Belgrade: Mladost).

Mamić, Z. (2004) Željko Joksimović zahvalio Hrvatima na "12 poena”, Novi list, 5 November.

Mamić, Z. (2005) Vlahovu zbog Ceca prijetili smrću, Novoj TV bombom, Novi list, 28 January.

Marinović, M. (2001) Još je prerano da pjevam u Srbiji, a oni se zabavljaju, Večernji list, 7 December. 
Marušić, A. (2004) Joksimović se stekao, tinejdžerice ludovale, Slobodna Dalmacija, 5 November.

Marušić, R. (2000) Ja sam kao vojnik, Slobodna Dalmacija, 21 December.

Mikac, N. (2004) Joksimović otvorio granice ex-Yu glazbi, Večernji list, 5 November.

Mikić, V. (2006) The way we (just me, myself and I) were: recycling (national) identities in recent popular music, presented at Musical Culture and Memory, University of Arts, Belgrade, 12-14 April.

Oremović, A. (2002) Porin potiho strahuje od Huljićeva bojkotiranja s Croatijom Records, Večernji list, 11 January.

Paštar, T. (2003) Cetinjani iščekuju Norčev povratak, Slobodna Dalmacija, 2 February.

Pavičić, J. (2005) Spoj kiča i katolicizma, Jutarnji list, 12 March.

Pavlović, T. (1999) Women in Croatia: feminists, nationalists and homosexuals, in: S. P. Ramet (Ed.), Gender Politics in the Western Balkans: Women and Society in Yugoslavia and the Yugoslav Successor States (University Park, PA: Pennsylvania State University Press).

Perasović, B. (2006) Youth, the media, and subculture in post-socialist societies, presented at RIME Workshop, Subotica, 11-13 May.

Perić, G. (1996) Pušenje zbog Zabranjenog pušenja, AIM, 27 April, available online at: http://www.aimpress.ch/dyn/pubs/archive/data/199604/60427-001-pubs-zag.htm [accessed 30 July 2004].

Peršić, V. (2000) Polemike i dvojbe uz prvi nastup Djordje Balaševića u samostalnoj Hrvatskoj, Novi list, 1 December.

Peršić, V. (2001) Mene hrvatska publika razumije i bez "titlovanja”, Novi list, 8 June.

Petranović, D. (2003a) Dokazivanje hrvatstva, Slobodna Dalmacija, 13 August.

Petranović, D. (2003b) Sezona suzavca, Slobodna Dalmacija, 14-15 August. 
Petranović, D. (2003c) Suzavac rasplakao Bajagu i Bačvice, Slobodna Dalmacija, 13 August.

Portes, A., L. E. Guarnizo, \& P. Landolt. (1999) The study of transnationalism: pitfalls and promise of an emergent research field, Ethnic and Racial Studies 22(2), pp. 21737.

Pribačić, D., and Z. Mamić (2002) I najbezazlenija riječ ima preveliku težinu, Novi list, 15 December.

Prica, I. (1991) Omladinska potkultura u Beogradu: simbolička praksa (Belgrade: Etnografski institute SANU).

Prica, I. (1993) Notes on everyday life in war, in: L. Čale Feldman, I. Prica \& R. Senjković (Ed.), Fear, Death and Resistance: An Ethnography of War: Croatia 19911992 (Zagreb: Institute of Ethnology and Folklore Research, 1993).

Rašević, M. (2005) MTV-jeva audicija 24. travnja u Splitu, Slobodna Dalmacija, 31 March.

Rasmussen, Lj. V. (2002) Newly-Composed Folk Music of Yugoslavia (London \& New York: Routledge).

Razsa, M., \& N. Lindstrom. (2004) Balkan is beautiful: Balkanism in the political discourse of Tuđman's Croatia, East European Politics and Societies 18(4), pp. 62850.

Rihtman-Auguštin, D. (2000) Ulice moga grada: antropologija domaćeg terena (Belgrade: Biblioteka XX vek).

Russell, P. A. (1997) Musical tastes and society, in: D. J. Hargreaves \& A. C. North (Ed.), The Social Psychology of Music (Oxford: Oxford University Press).

Šarac, D., \& M. Jelaca (2001) Povratak gladiatora, Slobodna Dalmacija, 18 June. 
Šćepanović, I. (2003) Neće biti incidenata jer ja odašiljem pozitivnu energiju, Slobodna Dalmacija, 3 December.

Senjković, R. (1993) In the beginning there was a coat of arms, a flag and a pleter, in: L. Čale Feldman, I. Prica \& R. Senjković (Ed.), Fear, Death and Resistance: An Ethnography of War: Croatia 1991-1992 (Zagreb: Institute of Ethnology and Folklore Research, 1993).

Senjković, R. (2002) Lica društva, likovi države (Zagreb: Biblioteka Nova etnologija).

Senjković, R., \& D. Dukić (2005) Virtual homeland?: reading the music on offer on a particular web page, International Journal of Cultural Studies 8(1), pp. 44-62.

Stanić, R. (2002) Balašević: Umalo da postanem muška Brena, Blic News, 20 November.

Stanivuković, Z. (2002) Naličje “istočnog greha”, NIN, 25 April.

Stanković, S. (2004) Aca Lukas najpopularniji, Blic, 31 March.

Stojčić, D. (2002) Kolobarić: može nastupiti u Osijeku, ali ne i u HNK-u, Glas Slavonije, 7 May.

Strukar, V. (2003a) Grčki Telecom s 250 tisuća dolara sponzorira moj spot za MTV, Novi list, 4 May.

Strukar, V. (2003b) Severina, Ceca i Lepa Brena zajedno pjevale u Sava centru!, Novi list, 13 March.

Strukar, V. (2004) Mikulić je dao sve od sebe, Novi list, 13 May.

Strukar, V., \& Z. Mamić (2003) Nikad mizernija kvaliteta pjesama, Novi list, 4 March.

Trajković, J. (2004) Srbi ugodno iznenadjeni, mnogi i šokirani, Jutarnji list, 17 May.

Turina, D. (2000) Dobro veče, Hrvatska, Novi list, 6 December.

Ugrešić, D. (1998) The Culture of Lies: Anti-Political Essays (London: Phoenix, 1998).

Uzelac, G. (1997) Franjo Tudjman's nationalist ideology, East European Quarterly 31(4), pp. 449-72. 
Velikonja, M. (2002) Ex-home: "Balkan culture" in Slovenia after 1991, in: S. Resić and B. Tornquist Plewa (Ed.), The Balkans in Focus: Cultural Boundaries in Europe, (Lund: Nordic Academic Press).

Vertovec, S. (1999) Conceiving and researching transnationalism, Ethnic and Racial Studies 22(2), pp. 447-62.

Vertovec, S. (2001) Transnationalism and identity, Journal of Ethnic and Migration Studies 27(4), pp. 573-82.

Vodopija, Z. (2004) Hrvatski sluh za srpski folk, Vjesnik, 18 May.

Volčič, Z. (2005) Belgrade vs. Serbia: spatial re-configurations of belonging, Journal of Ethnic and Migration Studies 31(4), pp. 639-58.

Volčič, Z. (forthcoming) Spaces of identity and belonging: narratives of young Macedonian and Slovenian intellectuals, Cultural Dynamic.

Vuković, Ž. (1998) Rambove turbo-folk karikature, Večernji list, 12 December.

Zakošek, N. (2000) The legitimation of war: political construction of a new reality, in: N. Skopljanac Brunner et al. (Ed.), Media and War (Zagreb: Centre for Transition and Civil Society Research; Belgrade: Agency Argument).

Žužić, B. (2002) Bajagin koncert u Labinu, Slobodna Dalmacija, 27 August. 